\title{
Phylogenetic study of the section Adonanthe of genus Adonis L. (Ranunculaceae) based on ITS sequences
}

\author{
Dong Chan Son, Beom Kyun Park ${ }^{1}$ and Sung Chul Ko ${ }^{1 *}$ \\ Division of Forest Biodiversity, Korea National Arboretum, Pocheon 11186, Korea \\ ${ }^{1}$ Department of Biological Sciences and Biotechnology, Hannam University, Daejeon 34054, Korea \\ (Received 27 January 2016; Revised 5 March 2016; Accepted 18 March 2016)
}

\section{ITS 염기서열에 의한 복수초속 복수초절(미나리아재비과)의 계통분류학적 연구}

\author{
손동찬 · 박범균 ${ }^{1}$ · 고성철 ${ }^{*}$ \\ 국립수목원 산림생물조사과, '한남대학교 생명나노과학대학 생명시스템과학과
}

\begin{abstract}
DNA sequences of nrITS regions obtained from 49 accessions representing 12 species and one variety within the section Adonanthe of the genus Adonis were analyzed to test the previous intra-sectional classification system and to determine their phylogenetic relationships. The results showed that the seven accessions of A. amurensis Regel et Radde included in the present study did not form a monophyletic group, as some of the accessions showed a close relationship with the Japanese endemic species $A$. ramosa Franch., which implies that the current species delimitation and identification of $A$. amurensis is problematic. Adonis pseudoamurensis W. T. Wang, which is frequently misidentified as $A$. ramosa in Korea, formed a segregated group, which suggests that they should not be considered as conspecific taxa. Accessions from A. shikokuensis Nishikawa et Koji Ito, A. multiflora Nishikawa et Koji Ito, and $A$. pseudoamurensis formed a clade, but monophyly of each species was not evident. The nrITS data did not support the classification system proposed by Wang, who classified sect. Adonanthe into four series, as most of these were found to be either polyphyletic or paraphyletic.
\end{abstract}

Keywords: Adonis, Adonanthe, phylogenetic analysis, sequence variation, ITS

적 요: 복수초속 복수초절 식물 12 종 1 변종과 4 종의 외군을 대상으로 복수초절 내 분류체계의 타당성을 검증하고 각 분류군 간의 유연관계를 규명하기 위하여 ITS 염기서열에 기초한 계통분류학적 연구를 수행하였다. 계통수 제작 결과 분석에 포함된 복수초(A. amurensis Regel et Radde) 7개체 중 일본에서 채집된 2개체가 일본 고유종인 가지복수초( $A$. ramosa Franch.)와 더 가까운 유연관계를 보였다. 이는 복수초가 단계통군이 아님을 말해주며, A. amurensis의 분류학적 정체성에 대한 재검토가 필요함을 암시한다. 국내에서 흔히 가지복수초로 동정되고 있는 개복수초(A. pseudoamurensis W. T. Wang)는 계통수 상에서 독자적인 그룹을 이루는 것으로 확인되었고, 따라서 개복수초를 가지복수초와 같은 종으 로 보는 견해를 뒷받침하지 않았다. A. shikokuensis Nishikawa et Koji Ito, 세복수초(A. multiflora Nishikawa et Koji Ito), 및 개복수초를 대표하여 분석에 포함된 개체들은 하나의 분기군(clade)을 이루었으나 각 종은 계통수 상에서 명확히 구분 되지 않았다. 본 연구 결과 ser. Amurenses와 ser. Coeruleae가 다계통군을 이루거나 측계통군을 이루는 것으로 확인되었 으며, 따라서 복수초절을 4 개의 열(series)로 분류한 Wang의 분류체계는 타당하지 않은 것으로 밝혀졌다.

주요어: 복수초속, 복수초절, 계통 분석, 염기서열 변이, ITS

*Author for correspondence: kscaaa@hnu.kr 
The genus Adonis L. belongs to the family Ranunculaceae and is composed of perennial and annual herbaceous plants that are included in the tribe Adonideae under the subfam. Ranunculoideae (Nishikawa and Kadota, 2006; Ren et al., 2009). Approximately 26-30 species grow in the northern temperate zone including Asia, Europe, and North America, and some annual plants are known to be distributed from Southwest Asia to North Africa, as well as along the shores of the Mediterranean (Meusel et al., 1965; Cronquist, 1981; Mabberley, 1990).

After the initial attempt by Linnaeus (1753), De Candolle (1818) established the classification system, including the genus Adonis at the section level, in which 10 taxa of this genus were divided into the sect. Adonia DC., an annual species with 5-10 petals, 18-20 stamens, erect styles, and cylindrical or globular aggregated achenes, and the sect. Consiligo DC., a perennial species with 8-15 petals, 25-30 stamens, recurved styles, and globular aggregated achenes. There have been various arguments on the classification of the sect. Consiligo DC. For instance, unlike the sect. Adonia DC., this group was subdivided into subsection levels (Bobrov, 1937; Poschkurlat, 1977; Tamura, 1990, 1991) and some taxa were treated as an independent genus (gen. Adonanthe Spach) or section (sect. Ancistrocarpium Spach) (Spach, 1839).

Through a morphological study on 30 taxa of the genus Adonis L. distributed globally that represented a comprehensive study of this genus, Wang (1994a, 1994b) promoted sect. Adonia (annual plants) and sect. Consiligo DC. (perennial plants) to the subgenus Adonis (DC.) W. T. Wang and subgen. Adonanthe (Spach) W. T. Wang, respectively. Furthermore it was suggested that the subgen. Adonis should be further divided into 3 sections and 2 series, while the subgen. Adonanthe should be divided into 3 sections and 4 series, resulting in a new classification system with 1 genus, 2 subgenera, 6 sections, and 6 series.

The sect. Adonanthe W. T. Wang in the subgen. Adonanthe is divided into the series Amurenses Poschk., which is characterized by ovate, ovate deltoid, or elliptic shaped leaves and yellow or white petals; ser. Coeruleae Poschk. with oblong or ovate oblong shaped leaves and white or purple petals; ser. Apenninae Bobr. ex Poschk. with 3-pinnately compound leaves; and ser. Vernales Bobr. ex Poschk. with 3-pinnatisect palmately compound leaves. Son and Ko (2013) have supported this classification system within the sect. Adonanthe based on the morphology of aggregated achenes and the microstructure of the achene surface in the genus Adonis L. found in East Asia; however, most of the previous studies on the genus Adonis L. mentioned above focused on the classification system based on morphological differences, including those associated with leaf shape and achene characters, whereas a phylogenetic relationship-based classification system of the genus Adonis L. has not yet been established. In addition, Son (2015) indicated that, although leaf shape and leaf type in the genus Adonis L. could be used for identification in some species, they were highly variable among individuals and in most cases generally did not provide any information for phylogenetic analysis.

Because plants of the sect. Adonanthe have similar external morphological characteristics that are highly variable and objective taxonomic characteristics of the taxa within the genus have not been established, it is difficult to identify taxa and investigate their phylogenetic relationships. A. davidii Franch. is a Chinese endemic species described by Franchet (1885), but it was considered a synonym of A. brevistyla Franch. (Wang, 1980). Later, it was reestablished as an independent taxon by Wang (1994a), whereas A. brevistyla was treated as a synonym of $A$. davidii by $\mathrm{Fu}$ and Robinson (2001), which shows the different opinions about the taxonomic status of these taxa.

Adonis pseudoamurensis W. T. Wang (Korean name: Gaebok-su-cho) was introduced as a new species by Wang (1980) based on samples collected in Jilin, China (C. Chen 1204, PE), but it was later considered a synonym of $A$. ramosa Franch. (Korean name: Ga-ji-bok-su-cho) along with $A$. multiflora Nishikawa et Koji Ito (Korean name: Se-bok-su-cho) by the same author (Wang, 1994a). However, Nishikawa and Kadota (2006) regarded A. ramosa as a Japanese endemic species and Wang's (1980) $A$. pseudoamurensis as a synonym of $A$. multiflora. In contrast, Lee et al. (2003) and Son and Ko (2012) recognized A. pseudoamurensis, A. multiflora, and A. ramosa as independent species. In addition, $A$. pseudoamurensis was treated as a variety of A. amurensis [var. pseudoamurensis (W. T. Wang) Y. N. Lee] (Lee, 2004, 2006). Thus diverse opinions have appeared about its taxonomic status.

Adonis coerulea Maxim. was described by Maximowicz (1877) based on samples collected from Gansu, China (N. M. Przewalski s.n., E). The species is characterized by plants glabrous; leaves oblong, 2-3 pinnately compound, with long petioles, densely arranged at the base of the stem; and petals purple. Based on the samples collected from Xizang, China (Z. Qing et al. 76-10534, PE), Wang (1980) designated the population with short pubescence on the stem and leaves, unlike glabrous f. coerulea, as f. puberula W. T. Wang, and later Wang (1994b) elevated it to var. puberula (W. T. Wang) W. T. Wang. However, Fu and Robinson (2001) considered var. puberula a synonym of the basic species and recorded it 
as a hairless plant except for pistils, adding further to the uncertainty of the taxonomic identity of the f. puberula population, which has been recognized for having short pubescence on the stem and leaves.

Recently, molecular data have been frequently used to establish a phylogenetic classification system. In particular, the ITS regions, which are nuclear DNA regions characterized by patterns of parental inheritance, evolve more rapidly than the coding regions, leading to higher levels of variation among closely related individuals. Thus, the ITS regions have been utilized to investigate inter-species and inter-genus relationships, as well as evolutionary trends and patterns in genetic variation (Baldwin, 1992; Álvarez and Wendel, 2003).

Previous studies on the genus Adonis L. in East Asia include sequence analyses of $t r n \mathrm{~L}-\mathrm{F}$ and the ITS region sequenced from Japanese Adonis plants (Kaneko et al., 2008) as well as an ITS sequence analysis from Korean Adonis plants (Suh et al., 2002). Additionally, despite the taxonomic applications of various DNA sequence analyses, which have been completed by a number of taxonomists, the genus Adonis L. has only been used as a control for studying relationships with other taxa within the family (Hoot, 1995; Sun et al., 2001; Després et al., 2003; Cai et al., 2009). Furthermore, no representatives from the entire taxa of the sect. Adonanthe under gen. Adonis L. in East Asia have been phylogenetically classified.

Thus, in the present study, we investigated the phylogenetic relationships of the sect. Adonanthe of genus Adonis L. using sequences from the ITS region of nuclear ribosomal DNA and aimed to evaluate the validity of the intra-genus classification system more objectively. In addition, we also attempted to address the taxa with species delimitation problems.

\section{Materials and Methods}

\section{Materials}

Plant samples from 11 taxa with 21 representative accessions from the sect. Adonanthe of genus Adonis were either collected directly from the field by the participants in this study or obtained from specimens that were deposited in herbaria (HNHM, PE, and KUN) in Korea and China. Nuclear acid sequence information for A. vernalis L. and A. shikokuensis Nishikawa et Koji Ito were retrieved from GenBank. Data from GenBank were also added for the taxa with different taxonomic status among the sect. Adonanthe. A. annua L. belongs to the sect. Adonis of subgen. Adonis, and Trollius acaulis Lindl., $T$. asiaticus L., and T. chinensis Bunge were selected as the outgroup (Johansson, 1999). The collection data regarding the 13 taxa with 49 accessions and 4 taxa as the outgroup with 4 accessions that were used in the present study are summarized in Table 1.

\section{DNA extraction, DNA amplification, and sequencing}

Leaf samples collected from specimens or the field were stored in silica gel until completely dehydrated and crushed using a grinder (Mixer Mill MM200, Retsch, Haan, Germany) or a mortar, and total genomic DNA was extracted using a DNA extraction kit ( $\mathrm{MG}^{\mathrm{TM}}$ Plant Genomic DNA Extraction SV mini, Macrogen, Seoul, Korea). Extracted DNA was assessed by electrophoresis using a $0.9 \%$ agarose gel. The reaction mixture utilized to amplify DNA using polymerase chain reaction (PCR) included $5 \mu \mathrm{L} 10 \times$ Pfu DNA buffer, $1 \mu \mathrm{L}$ $10 \mathrm{mM}$ dNTP, $1 \mu \mathrm{L} 10 \mathrm{pmol}$ primers in each direction, 25100 ng template DNA, $0.5 \mu \mathrm{L}$ Pfu DNA polymerase, and $41.5 \mu \mathrm{L}$ D.W. in a total volume of $50 \mu \mathrm{L}$. The primers used for DNA amplification were ITS4 and ITS5 (White et al., 1990). PCR conditions for gene amplification were as follows: the reaction began with a pre-denaturation step at $94^{\circ} \mathrm{C}$ for 5 min, followed by 35 thermal cycles of denaturation at $94^{\circ} \mathrm{C}$ for $30 \mathrm{sec}$, annealing at $52^{\circ} \mathrm{C}$ for $1.5 \mathrm{~min}$, and extension at $72^{\circ} \mathrm{C}$ for $1.5 \mathrm{~min}$, followed by a final extension at $72^{\circ} \mathrm{C}$ for 7 min. The PCR product was purified with a commercial kit (PCR Purification Kit, Macrogen, Korea), followed by cycle sequencing using a BigDye ${ }^{\circledR}$ terminator v3.1 Cycle Sequencing Kit (Applied Biosystems, USA). Sequences were analyzed using the ABI PRISM 3730XL Analyzer (Applied Biosystems, USA). Sequences were deposited to GenBank and accession numbers were obtained (KU570388-KU570408).

\section{Alignment of DNA sequences and analyses of phylogeny}

DNA sequences for each sample in both the forward and reverse orientations were assembled and aligned using Geneious ver. 7.1.7 (Biomatters, Ltd., Auckland, New Zealand), and final alignments were manually verified. Maximum Parsimony analysis (MP) and Maximum Likelihood (ML) were conducted using PAUP* ver. 4.0b10 (Swofford, 2003). Heuristic search was carried out with ACCTRAN, MULPARS, and TBR branch swapping options turned on. To determine the support levels for the resulting cladograms, the bootstrap values (Felsentein, 1985) and posterior probabilities (PP) from the Bayesian inference were determined. Bootstrap values were obtained from 1,000 bootstrap replicates. To calculate the posterior probabilities using a Bayesian inference, a substitution model best fit to each set of sequence data was selected based on Akaike Information Criterion (AIC; Posada and Buckley, 2004) using Modeltest ver. 3.7 (Posada and 
Table 1. List of taxa used for the ITS analysis with vouchers and Genbank accession numbers.

\begin{tabular}{|c|c|c|c|c|}
\hline Taxa & Abbr. & Locality and Voucher & Ribotype & Accession No. \\
\hline A. davidii Franch. & DAV1 & Yunnan, China $02577(\mathrm{PE})$ & Z2(27NS, 2ID) & KU570394 \\
\hline A. brevistyla Franch. & BRE1 & ?, China & $\mathrm{Z}(26 \mathrm{NS}, 3 \mathrm{ID})$ & KF233849* \\
\hline A. brevistyla Franch. & BRE2 & Shaanxi, China 2 (KUN) & Z1(27NS, 2ID) & KU570392 \\
\hline A. sutchuenensis Franch. & SUT1 & Sichuan, China 70817 (PE) & $\mathrm{T}(19 \mathrm{NS}, 2 \mathrm{ID})$ & KU570406 \\
\hline A. sutchuenensis Franch. & SUT2 & Hubei, China 22832 (PE) & U(19NS, 2ID) & KU570407 \\
\hline A. sutchuenensis Franch. & SUT3 & Gansu, China 1383 (PE) & $\mathrm{V}(20 \mathrm{NS}, 2 \mathrm{ID})$ & KU570408 \\
\hline A. amurensis Regel et Radde & AMU1 & Mt. Unmu, Gangwon, Korea s.n. (HNHM) & $\mathrm{D}(9 \mathrm{NS})$ & KU570388 \\
\hline A. amurensis Regel et Radde & AMU2 & Mt. Odae, Gangwon, Korea s.n. (HNHM) & $\mathrm{D}(9 \mathrm{NS})$ & KU570389 \\
\hline A. amurensis Regel et Radde & AMU3 & Daekwanryung, Gangwon, Korea & $\mathrm{E}(10 \mathrm{NS}, 2 \mathrm{ID})$ & AF454929* \\
\hline A. amurensis Regel et Radde & AMU4 & Mt. Chookryung, Gyeonggi, Korea & $\mathrm{F}(10 \mathrm{NS})$ & AF454928* \\
\hline A. amurensis Regel et Radde & AMU5 & Mt. Jeoksang, Jeonbuk, Korea & $\mathrm{E}(10 \mathrm{NS}, 2 \mathrm{ID})$ & AF454927* \\
\hline A. amurensis Regel et Radde & AMU6 & Nemuro, Hokkaido, Japan & A & AB361619* \\
\hline A. amurensis Regel et Radde & AMU7 & Shari, Hokkaido, Japan & A & AB361620* \\
\hline A. ramosa Franch. & RAM1 & Fujimi, Nagano, Japan s.n. (HNHM) & A & KU570403 \\
\hline A. ramosa Franch. & RAM2 & Hokkaido, Japan, Komineyama-4 (PE) & $\mathrm{C}(4 \mathrm{NS})$ & KU570404 \\
\hline A. ramosa Franch. & RAM3 & Fujisato, Akita, Japan & A & AB361613* \\
\hline A. ramosa Franch. & RAM4 & Hachinohe, Aomori, Japan & A & AB361612* \\
\hline A. ramosa Franch. & RAM5 & Tadami, Fukushima, Japan & A & AB361615* \\
\hline A. ramosa Franch. & RAM6 & Asahi, Gifu, Japan & $\mathrm{B}(1 \mathrm{ID})$ & AB361617* \\
\hline A. ramosa Franch. & RAM7 & Urakawa, Hokkaido, Japan & A & AB361610* \\
\hline A. ramosa Franch. & RAM8 & Furano, Hokkaido, Japan & A & AB361611* \\
\hline A. ramosa Franch. & RAM9 & Mt. Fujiwara, Mie, Japan & $\mathrm{B}(1 \mathrm{ID})$ & AB361618* \\
\hline A. ramosa Franch. & RAM10 & Ina, Nagano, Japan & $\mathrm{B}(1 \mathrm{ID})$ & AB361616* \\
\hline A. ramosa Franch. & RAM11 & Yonezawa, Yamagata, Japan & A & AB361614* \\
\hline A. pseudoamurensis $\mathrm{W}$. T. Wang & PSE1 & Saengil lsland, Jeonnam, Korea s.n. (HNHM) & $\mathrm{M}(16 \mathrm{NS})$ & KU570398 \\
\hline A. pseudoamurensis $\mathrm{W}$. T. Wang & PSE2 & Donghae-si, Gangwon, Korea s.n. (HNHM) & $\mathrm{N}(16 \mathrm{NS})$ & KU570399 \\
\hline A. pseudoamurensis W. T. Wang & PSE3 & Pung lsland, Gyeonggi, Korea s.n. (HNHM) & $\mathrm{O}(16 \mathrm{NS})$ & KU570400 \\
\hline A. pseudoamurensis $\mathrm{W}$. T. Wang & PSE4 & Hyoganchi, Jeonbuk, Korea s.n. (HNHM) & $\mathrm{G}(14 \mathrm{NS})$ & KU570401 \\
\hline A. pseudoamurensis $\mathrm{W}$. T. Wang & PSE5 & Jangbong lsland, Gyeonggi, Korea & H(14NS) & $\mathrm{AF} 454935^{*}$ \\
\hline A. pseudoamurensis $\mathrm{W}$. T. Wang & PSE6 & Euyung, Gyeongnam, Korea & $\mathrm{J}(15 \mathrm{NS})$ & AF454930* \\
\hline A. pseudoamurensis $\mathrm{W}$. T. Wang & PSE7 & Mt. Palgong, Gyeongbuk, Korea & G(14NS) & $\mathrm{AF} 454932 *$ \\
\hline A. pseudoamurensis $\mathrm{W}$. T. Wang & PSE8 & Gwanchon, Jeonbuk, Korea & G(14NS) & AF454931* \\
\hline A. pseudoamurensis $\mathrm{W}$. T. Wang & PSE9 & Mt. Gyeryong, Chungnam, Korea & $\mathrm{K}(15 \mathrm{NS})$ & AF454933* \\
\hline A. pseudoamurensis $\mathrm{W}$. T. Wang & PSE10 & Chollipo, Chungnam, Korea & $\mathrm{K}(15 \mathrm{NS})$ & AF454934* \\
\hline A. multiflora Nishikawa et Koji Ito & MUL1 & Mulchatoreum, Jeju, Korea s.n. (HNHM) & $\mathrm{L}(15 \mathrm{NS})$ & KU570395 \\
\hline A. multiflora Nishikawa et Koji Ito & MUL2 & Seondeoksa, Jeju, Korea s.n. (HNHM) & $\mathrm{L}(15 \mathrm{NS})$ & KU570396 \\
\hline A. multiflora Nishikawa et Koji Ito & MUL3 & Kwaneumsa, Jeju, Korea s.n. (HNHM) & $\mathrm{L}(15 \mathrm{NS})$ & KU570397 \\
\hline A. multiflora Nishikawa et Koji Ito & MUL4 & Sangumburi, Jeju, Korea & $\mathrm{G}(14 \mathrm{NS})$ & AF454926* \\
\hline A. multiflora Nishikawa et Koji Ito & MUL5 & Eorimok. Jeju, Korea & $\mathrm{G}(14 \mathrm{NS})$ & AF454925* \\
\hline A. multiflora Nishikawa et Koji Ito & MUL6 & Kawai, Gifu, Japan & I(15NS, 1ID) & AB361621* \\
\hline
\end{tabular}


Table 1. Continued.

\begin{tabular}{|c|c|c|c|c|}
\hline Taxa & Abbr. & Locality and voucher & Ribotype & Accession No. \\
\hline A. multiflora Nishikawa et Koji Ito & MUL7 & Shoubara, Hiroshima, Japan & $\mathrm{I}(15 \mathrm{NS}, 1 \mathrm{ID})$ & AB361622* \\
\hline A. shikokuensis Nishikawa et Koji Ito & SHI1 & Kouchi, Japan & G(14NS) & AB361623* \\
\hline A. coerulea Maxim. & COE1 & Xizang, China, 91-459 (KUN) & $\mathrm{S}(19 \mathrm{NS}, 1 \mathrm{ID})$ & KU570393 \\
\hline $\begin{array}{l}\text { A. coerulea var. puberula (W. T. Wang) } \\
\text { W. T. Wang }\end{array}$ & PUB1 & Xizang, China, 90-433 (KUN) & Q(18NS, 1ID) & KU570402 \\
\hline A. sibirica (Patrin ex DC.) Patrin ex Ledeb. & SIB1 & ?, China, 2427 (PE) & Q(18NS, 1ID) & KU570405 \\
\hline A. bobroviana Simonovich & BOB1 & Gansu, China, 4098 (KUN) & $\mathrm{P}(18 \mathrm{NS}, 1 \mathrm{ID})$ & KU570390 \\
\hline A. bobroviana Simonovich & ВОВ2 & Gansu, China, 3914 (PE) & $\mathrm{X}(21 \mathrm{NS}, 2 \mathrm{ID})$ & KU570391 \\
\hline A. vernalis $\mathrm{L}$. & VER1 & Germany, Chase $9776(\mathrm{~K})$ & $\mathrm{Y}(22 \mathrm{NS}, 1 \mathrm{ID})$ & AJ347910* \\
\hline A. vernalis $\mathrm{L}$. & VER2 & Mt. Cserhat, Hungary & $\mathrm{W}(20 \mathrm{NS})$ & AF454936* \\
\hline A. апnиa L. (outgroup) & - & Jadin des Plantes, Paris, France & Out(52NS, 2ID) & AY148280* \\
\hline Trollius acaulis Lindl. (outgroup) & - & Jadin des Plantes, Paris, France & Out(40NS, 3ID) & AY $148265^{*}$ \\
\hline Trollius asiaticus L. (outgroup) & - & Novosibirsk, Soberia, Russia & Out(39NS, 3ID) & AY148267* \\
\hline Trollius chinensis Bunge (outgroup) & - & Kew Gardens, London, UK & Out(39NS, 3ID) & AY148268* \\
\hline
\end{tabular}

The number of variable sites compared with ribotype A is shown in parentheses; NS, Nucleotide substitution; ID, Insertion/Deletion.

*, Cited ITS sequence data in NCBI (National Center for Biotechnology Information).

Crandall, 1998). After the best model was selected, $2 \times 10^{6}$ generations were run with the Markov chain Monte Carlo method (MCMC; Hastings, 1970) using MrBayes ver. 3.1.2 (Huelsenbeck and Ronquist, 2001), and then posterior probabilities were calculated after discarding the burn-in sample (initial 500,000 generations).

Furthermore, a tree topology built using the Neighbor Joining method (NJ) (Saitou and Nei, 1987; Farris et al., 1995) and pairwise sequence divergence was calculated by the Kimura two-parameter method (Kimura, 1980).

\section{Results}

\section{Sequences of nrDNA ITS region}

The total DNA sequence length of the ITS region from 49 accessions representing 13 taxa in the sect. Adonanthe was 597-601 bp, and the total length of the aligned sequences was 604 bp. The length of ITS 1 and ITS 2 was 232-234 bp and 201-203 bp, respectively, showing that the length of ITS 1 was longer than that of ITS 2 . The length of the $5.8 \mathrm{~S}$ region was 164-165 bp, which was similar to that in other flowering plants (161-164 bp).

Pairwise distance between taxa calculated using Kimura's two parameter method revealed that sequence divergence of the ITS regions across 53 samples, including the outgroup, was 0$9.873 \%$; and sequence divergence among 49 samples, excluding the outgroup, was relatively high $(0-6.106 \%)$. In the data set that included outgroups, taxa without intraspecific sequence variation included $A$. ramosa (RAM1, RAM3, RAM4, RAM5, RAM7, RAM8, and RAM11), A. amurensis (AMU6 and AMU7), A. shikokuensis (SHI1), A. pseudoamurensis (PSE4, PSE7, and PSE8), and $A$. multiflora (MUL4 and MUL5) (Table 1). The highest sequence divergence was observed between $A$. annua and $A$. amurensis (AMU1). Among the ingroups, $A$. davidii (DAV1) and $A$. amurensis (AMU3 and AMU5) were the taxa with the highest sequence divergence $(6.106 \%)$.

\section{Phylogenetic analyses}

$\mathrm{NJ}$ analysis based on sequence divergence resolved the species of the Adonis sect. Adonanthe largely into four clades (Fig. 1). Clade I comprised A. sutchuenensis Franch., $A$. davidii, and $A$. brevistyla from ser. Amurenses and A. coerulea and $A$. coerulea var. puberula from ser. Coeruleae; it was resolved as the most basal, forming a sister group with other clades. Then $A$. vernalis from ser. Vernales (clade II) diverged, and clade III including $A$. bobroviana Simonovich and $A$. sibirica (Patrin ex DC.) Patrin ex Ledeb. from ser. Apenninae diverged after $A$. vernalis. Clade IV comprised two subclades, subclade 1 consisting of $A$. pseudoamurensis, A. multiflora, and A. shikokuensis, and subclade 2 including $A$. amurensis, and A. ramosa, which is congruent with the phylogenetic tree inferred from MP analysis (Fig. 2). Within the subclade 1, some accessions (PSE4, PSE7, PSE8, MUL4, and MUL5) possessed the same ITS sequences with $A$. 


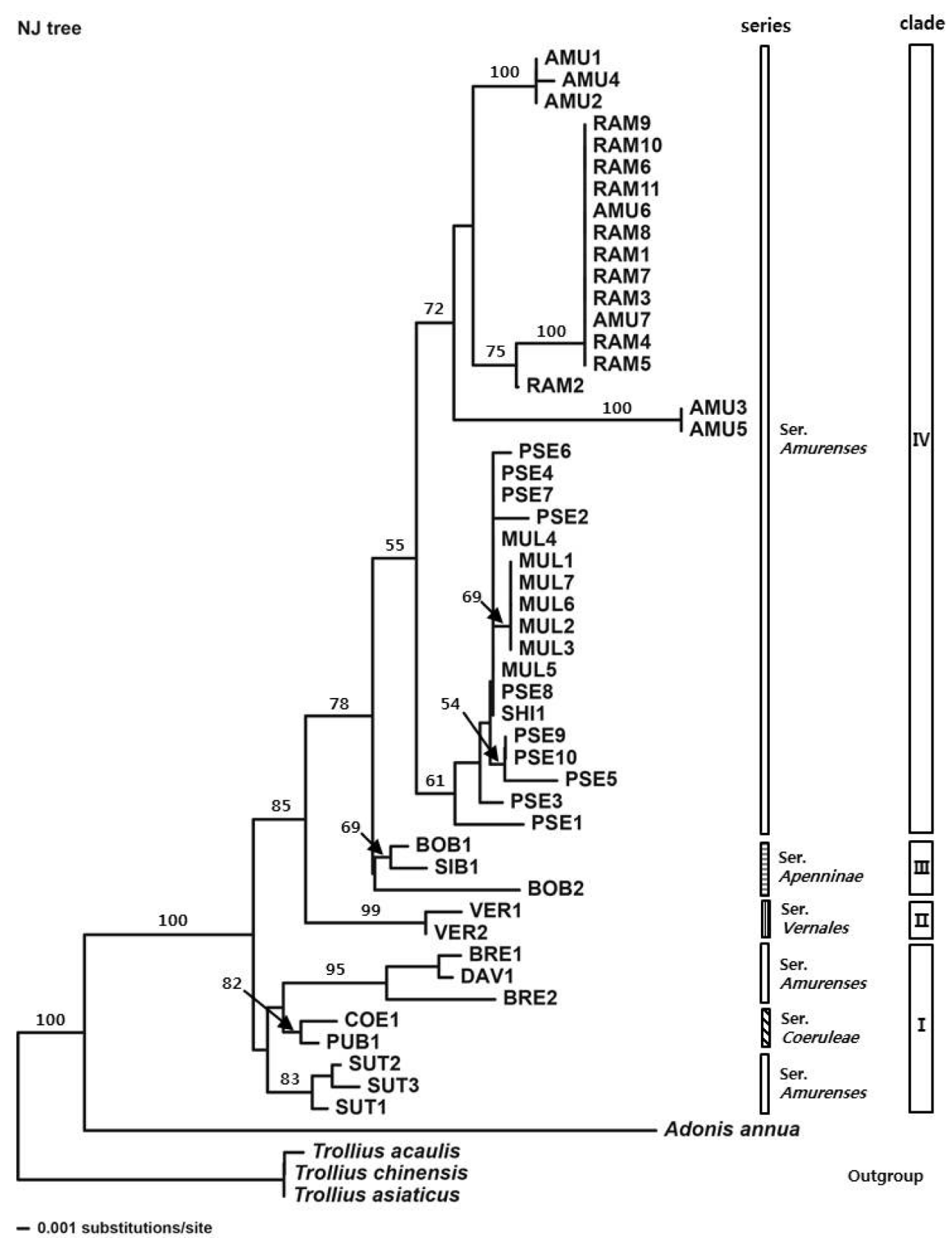

Fig. 1. Neighbor-Joining (NJ) tree inferred from nrDNA ITS sequences of the section Adonanthe under genus Adonis and its related genera by Kimura-two parameter distance. The numbers on branches indicate bootstrap values higher than $50 \%$. Refer to Table 1 for accession abbreviation.

shikokuensis (Table 1). Also, two accessions (AMU6 and AMU7) of $A$. amurensis were located in the same subclade as $A$. ramosa, showing a genetically close relationship between these taxa.

MP analysis of the ITS regions resulted in 34 equally parsimonious trees with a tree length of 170 steps, in which the CI (Consistency Index), RI (Retention Index), and RC (Rescaled Consistency Index) were 0.800, 0.931, and 0.744, respectively. The total length of the aligned sequences was 604 bp, of which, 115 were variable sites and 76 were parsimony informative sites.

In the parsimony tree (Fig. 2), the sect. Adonanthe of genus Adonis L. formed a monophyletic group consisting of 4 clades. The sect. Adonanthe had bootstrap values less than $50 \%$ for divergence of a clade (clade I) composed of A. sutchuenensis, A. coerulea, A. coerulea var. puberula, A. davidii, and A. 


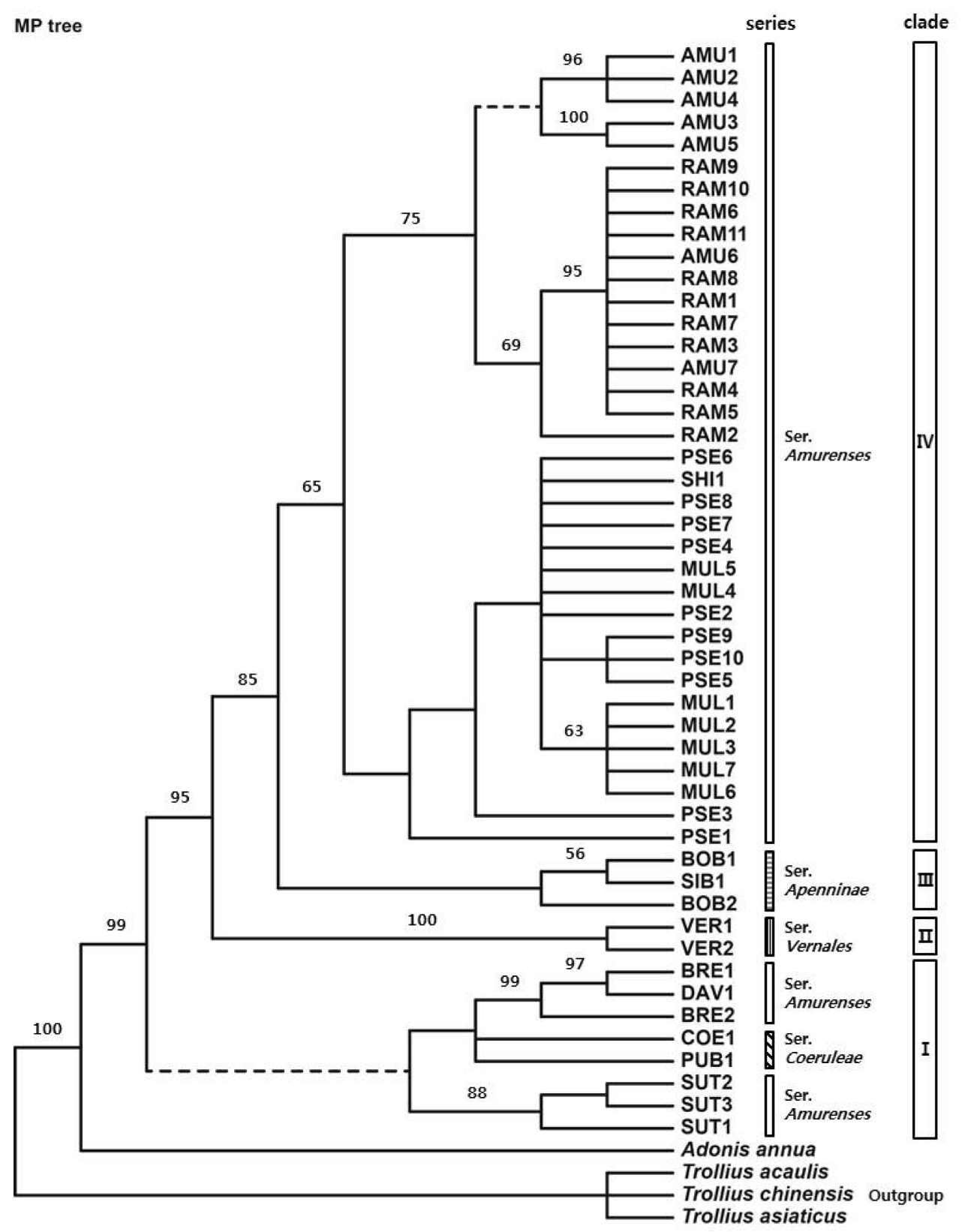

Fig. 2. One of the 34 equally most-parsimonious trees $(170$ steps, $\mathrm{CI}=0.800, \mathrm{RI}=0.931, \mathrm{RC}=0.744)$ based on nrDNA ITS sequences of the section Adonanthe of genus Adonis and outgroup taxa. The numbers above branches indicate bootstrap values higher than $50 \%$. Dashed lines indicate nodes that collapse in the strict consensus tree. Refer to Table 1 for accession abbreviation.

brevistyla. In this clade, A. sutchuenensis formed a subclade with an $88 \%$ bootstrap value, and a sister subclade composed of A. davidii, A. brevistyla, A. coerulea, and A. coerulea var. puberula was formed. A. vernalis (clade II) diverged with a $100 \%$ bootstrap value, and a clade III composed of $A$. bobroviana and $A$. sibirica diverged with a bootstrap value less than 50\%. In addition, a subclade composed of $A$. pseudoamurensis, A. multiflora, and A. shikokuensis and a subclade composed of $A$. amurensis and $A$. ramosa formed clade IV with a bootstrap value of $65 \%$. Ser. Amurenses formed a polyphyletic group with representatives present in clade I and clade IV.

ML analysis (Fig. 3) showed monophyly of the genus Adonis sect. Adonanthe with bootstrap values of $100 \%$ and a Bayesian posterior probabilities value of 1.00 . The clade I observed on the NJ and MP tree was not evident in the ML tree. A. vernalis diverged with a bootstrap value of $100 \%$ and a Bayesian posterior probabilities value of 1.00 (clade II). Clade III 


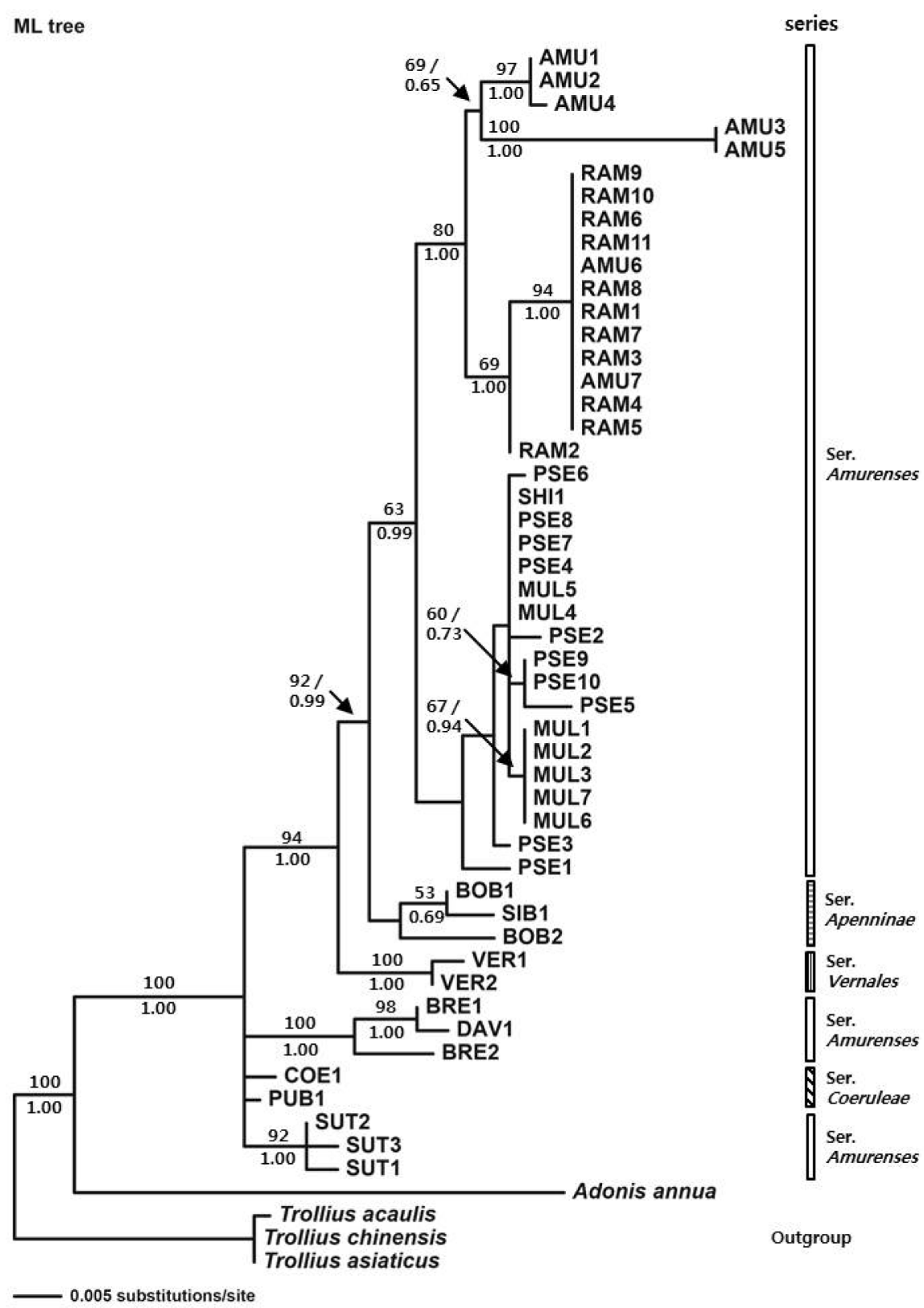

Fig. 3. Maximum Likelihood (ML) analysis of nrDNA ITS sequences of the section Adonanthe of genus Adonis and outgroup taxa. The numbers above and below branches indicate bootstrap values higher than $50 \%$ and Bayesian posterior probability, respectively. Refer to Table 1 for accession abbreviation.

composed of $A$. bobroviana and A. sibirica formed a sister group with clade IV composed of $A$. pseudoamurensis, $A$. multiflora, A. shikokuensis, A. amurensis, and A. ramosa with a bootstrap value of $92 \%$ and a Bayesian posterior probabilities value of 0.99 . A subclade composed of $A$. amurensis and $A$. ramosa within clade IV formed a sister group with a subclade composed of A. pseudoamurensis, A. multiflora, and A. shikokuensis with a bootstrap value of $63 \%$ and a Bayesian posterior probabilities value of 0.99 .

\section{Discussion}

A phylogenetic study using ITS sequences was conducted for 13 taxa that belong to the sect. Adonanthe of genus Adonis provided valuable information for the classification of the taxonomically problematic section. Although the ITS trees mostly supported monophyly of ser. Vernales and ser. Apenninae, the taxa in ser. Amurenses did not form a monophyletic group (Figs. 1-3). The polyphyly of ser. 
Amurenses is probably due to genetic divergence caused by disjunctive distribution of the members in the series (A. davidii, A. brevistyla, and $A$. sutchuenensis in mid-western China and other taxa in northeastern China, Korea, and Japan). These results are inconsistent with the classification system proposed by Wang (1994a, 1994b).

Meanwhile, the taxa in the clade I (Figs. 1, 2), which is composed of $A$. davidii, A. brevistyla, and A. sutchuenensis in ser. Amurenses and A. coerulea and A. coerulea var. puberula in ser. Coeruleae, grow in fruticeta or grasslands at an elevation of 1,500-3,000 $\mathrm{m}$ in the mid-southern, southwestern, and western areas in China and are characterized by elongated and lignified rhizomes. This is in contrast with those taxa found in northeastern China, Korea, and Japan, including the distinct clade IV (A. amurensis, A. ramosa, A. pseudoamurensis, A. multiflora, and $A$. shikokuensis), which have short rhizomes and are surrounded by fibrous roots. In the strict consensus tree (Fig. 2), however, clade I composed of $A$. sutchuenensis, A. coerulea, $A$. coerulea var. puberula, A. davidii, and A. brevistyla collapsed, which is consistent with the results from the ML analysis (Fig. 3). Despite forming a clade in the NJ analysis (Fig. 1), either the bootstrap value supporting the clade I was low or the taxa examined did not form a monophyletic group depending on the analysis method implemented. Thus, further studies are needed to resolve the phylogenetic relationships among these groups in relation to the evolutionary trends of morphological characters.

There have been many different opinions regarding the taxonomic identities and phylogenetic relationships of the taxa that belong to the sect. Adonanthe. It is known that the members of sect. Adonanthe have similar morphological characters with severe variations, which hindered establishment of dependable taxonomic characters within the section. $A$. davidii and $A$. brevistyla formed a subclade with bootstrap value of $99 \%$ in the MP analysis (Fig. 2), which revealed that they are genetically related taxa. It is noticeable that BRE1 and BRE2 in A. brevistyla did not form a clade in all ITS trees (Figs. 1-3). Depending on the taxonomists, A. davidii and $A$. brevistyla have been considered either conspecific (Wang, 1980; Fu, 2000; Fu and Robinson, 2001) or treated as independent species (Wang, 1994a). Since it is possible that $A$. davidii was misidentified as BRE1 in the present study, a taxonomic study based on the original description and a type specimen should be performed to validate the identities of these taxa. Meanwhile, Wang (1994a, 1994b) suggested that A. davidii was the most primitive species in the sect. Adonanthe. However, clade I collapsed in the strict consensus tree, making the group consisting of A. davidii, A. sutchuenensis, A. coerulea, and A. coerulea var. puberulea is paraphyletic, which is inconsistent with the taxonomic opinion of Wang (1994a, 1994b). Nevertheless, A. davidii is positioned at the base of sect. Adonanthe in MP, NJ, and ML analyses (Figs. 1-3). In addition, the species has ancestral characters, including long rhizomes, long petioles, oval lobules, and short persistent styles with recurved ends and is found in the southwestern region of China. This region is the center of origin for the genus Adonis L., and for this reason it has been considered to be the progenitor species of the sect. Adonanthe (Wang, 1994a, 1994b; Son, 2015).

Adonis coerulea and A. coerulea var. puberula were clustered together in the NJ analysis (Fig. 1), yet they did not form a clade in MP and ML trees (Figs. 2, 3). In some cases, A. coerulea var. puberula has been considered as a synonym of A. coerulea by Fu and Robinson (2001); thus, use of multiple samples collected from diverse areas and employment of phylogenetically useful DNA regions is imperative in order to confirm their taxonomic identities.

Although A. sutchuenensis, an endemic Chinese species, is superficially similar to A. amurensis, it is clearly distinguished by following morphological characters: the leaf shape is ovate pentagon and the sepal is shorter and narrower than the petal (Franchet, 1894). Within the ITS trees, multiple accessions representing A. sutchuenensis formed a strong monophyletic group, supporting the species is clearly distinct from other taxa within the sect. Adonanthe; therefore, it is reasonable to treat it as an independent species.

Adonis vernalis formed a sister clade with the group composed of clade IV (including representatives in ser. Amurenses found in northeastern China, Korea, and Japan) and clade III (ser. Apenninae distributed in mid-western China, Mongolia, Russia, and Kazakhstan), indicating that it is directly related to these groups (Figs. 1-3). In the sect. Adonanthe, A. vernalis is the only taxon distributed in Europe and Central Asia; therefore, it is thought that $A$. vernalis diverged and formed a distinct species when it moved from the western Himalayas to Europe. This divergence within the genus Adonis L. appears to support the views that the plants of the sect. Adonanthe (excluding $A$. vernalis) underwent speciation either after being transmitted along the route from southwestern China to Eastern Siberia via the northeastern Chinese region or from southwestern China to North Asia (Wang, 1994a, 1994b; Son, 2015).

Although the support for the clade is not sufficient, all ITS trees recognized monophyly of ser. Apenninae, which is supported by distinctive morphological characters such as lack of petioles (all other taxa of the sect. Adonanthe have petioles). Phylogenetic analysis, however, revealed that $A$. bobroviana is not monophyletic. The morphological characteristics of $A$. 
bobroviana, including glandular hairs on the stem and leaf, persistent style characterized by being recurved in a hook shape, and parallel achene surfaces, are clearly distinct from those of A. sibirica (Fu and Robinson, 2001; Son and Ko, 2013).

Adonis ramosa was treated either as a Japanese endemic species (Nishikawa and Kadota, 2006) or the same species as $A$. pseudoamurensis, which is found in Korea and China (Wang and Liu, 1988; Wang, 1994a, 1998; Fu and Robinson, 2001; Park, 2007). Additionally, A. pseudoamurensis was considered to be the same species as A. multiflora found in Korea and Japan (also reported in China; Nishikawa and Kadota, 2006); thus, there has been confusion concerning taxonomic identities of the taxa. The MP, NJ, and ML analyses of the ITS sequences distinguished $A$. ramosa from A. pseudoamurensis and revealed that A. multiflora was a distinct clade (Figs. 1-3). Morphologically, A. ramosa has hairs on the abaxial side of the leaf and its sepal length is similar to that of the petals. In contrast, A. pseudoamurensis and A. multiflora have no hair on the abaxial side of the leaves and the sepals are shorter than the petals. In addition, since A. pseudoamurensis has distinctive traits from $A$. multiflora with respect to the morphology of the leaf apex and lobule and microstructure of the achene surface (Son and Ko, 2012, 2013), it is reasonable to treat these species as independent taxa. With respect to chromosome number in the somatic cells, A. ramosa is a tetraploid plant with $2 n=32$ (Nishikawa, 1988, 1989), whereas A. pseudoamurensis is a diploid plant with $2 n=16$ (Son, 2011). Thus, it is unlikely that $A$. ramosa is distributed in Korea and China (Wang and Liu, 1988; Wang, 1994a, 1998; Fu and Robinson, 2001; Park, 2007). Instead, it appears to be reasonable to consider the species to be a Japanese endemic species (Suh et al., 2002; Lee et al., 2003; Nishikawa and Kadota, 2006). On the other hand, A. ramosa and A. amurensis formed a subclade with a bootstrap value of $75 \%$ in the MP tree (Fig. 2), indicating they are closely related taxa. However, the Korean A. amurensis and Japanese $A$. amurensis groups formed distinctive subclades. Interestingly, the Japanese $A$. amurensis accessions and the accessions of $A$. ramosa (RAM1, RAM3, RAM4, RAM5, RAM7, RAM8, and RAM11) had identical DNA sequences (Table 1). Geographically, A. ramosa is distributed in Hokkaido and northern to mid Honshu (Nishikawa and Kadota, 2006), and this area overlaps with that of $A$. amurensis in the eastern Hokkaido region (Nishikawa and Takeshima, 1992; Nishikawa, 1994). This is consistent with the theory of Kaneko et al. (2008), which speculated that $A$. ramosa should be an autotetraploid and the diploid progenitor of A. ramosa should be A. amurensis from the Hokkaido region. Since only 2 ITS ribotypes in $A$. ramosa were examined (Table 1), the data may not be sufficient to determine the process of speciation. However, the geographical distribution of organisms related to their ITS ribotypes was clearly distinct (Kaneko et al., 2008), implying the identical DNA sequence between the Japanese $A$. amurensis and $A$. ramosa appears to be due to a relatively recent speciation event.

For the Korean A. amurensis, the MP, NJ, and ML analyses divided the group into two subgroups (Figs. 1-3), which was attributed to the differences in the insertion/deletion of sequences (Table 1). However, no clear relationship was observed between the geographical distributions of these individuals and the ribotypes of each sample.

The ITS sequence analysis of $A$. pseudoamurensis revealed high levels of variation within the species (Table 1). This result is consistent with the report of Suh et al. (2002) that A. pseudoamurensis, unlike A. amurensis and A. multiflora, showed a high level of genetic variation in RAPD analysis. The high genetic variation in A. pseudoamurensis is probably the result of adaptation to diverse habitats in wide geographical areas of the species which ranges from northeastern China to southern part of the Korean Peninsula including islands on the west to south coast as well as lowland regions. Meanwhile, ITS trees indicated that $A$. pseudoamurensis is clearly distinct from $A$. amurensis (Figs. 1-3). In morphology, A. amurensis has an unbranched stem and its leaves emerge after the inflorescence has developed, whereas A. pseudoamurensis has a branched stem and its leaves and flowers develop at the same time; these differences together with phylogenetic data further validate recognition of $A$. pseudoamurensis as an independent species (Lee et al., 2003; Son and Ko, 2011, 2012) rather than as a variety of A. amurensis (Lee, 2004, 2006).

Some accessions of $A$. multiflora formed a subclade with a bootstrap value of $63 \%$ in MP analysis (Fig. 2). Additionally, the Sangumburi (MUL4) and Eorimok (MUL5) accessions were similar to A. shikokuensis that is distributed in Honshu, Shikoku, and Kyushu in Japan as well as to other groups (PSE4, PSE7, and PSE8) of the Korean $A$. pseudoamurensis (Figs. 2, 3, Table 1). This result suggest that $A$. shikokuensis might be related with either $A$. pseudoamurensis or A. multiflora, contradicting the hypothesis proposed by Nishikawa and Ito (2001), who suggested A. shikokuensis diverged from A. ramosa. However, further studies including more diverse samples and additional molecular markers are necessary to resolve the relationship among these taxa and obtain a reliable phylogenetic tree. 


\section{Acknowledgments}

This work was supported by 2015 Hannam University Research Fund.

\section{Literature Cited}

Álvarez, I. and J. F. Wendel. 2003. Ribosomal ITS sequences and plant phylogenetic inference. Molecular Phylogenetics and Evolution 29: 417-434.

Baldwin, B. G. 1992. Phylogenetic utility of the internal transcribed spacers of nuclear ribosomal DNA in plants: an example from the Compositae. Molecular Phylogenetics and Evolution 1: 3-16.

Bobrov, E. G. 1937. Adonis. In Flora of the U.S.S.R. Komarov, V.L. (ed), Koeltz Scientific Book, Koenigstein, Germany. 7: 403-411. (in Russian)

Cai, Y. F., S. W. Li, Y. Liu, S. Quan, M. Chen, Y. F. Xie, H. Z. Jiang, E. Z. Wei, N. W. Yin, L. Wang, R. Zhang, C. L. Huang, X. H. He and M. F. Jiang. 2009. Molecular phylogeny of Ranunculaceae based on internal transcribed spacer sequences. African Journal of Biotechnology 8: 5,215-5,224.

Cronquist, A. 1981. An Integrated System of Classification of Flowering Plants. Columbia Univ. Press, New York.

De Candolle, A. P. 1818. Adonis. In Regni Vegetabilis Systema Naturale. Vol. 1. De Candolle, A. P. (ed.), Sumptibus Sociorum Treuttel et Wurtz, Paris. Pp. 220-226.

Després, L., L. Gielly, B. Redoutet and P. Taberlet. 2003. Using AFLP to resolve phylogenetic relationships in a morphologically diversified plant species complex when nuclear and chloroplast sequences fail to reveal variability. Molecular Phylogenetics and Evolution 17: 185-196.

Farris, J. S., M. Källersjo, A. G. Kiuge and C. Bult. 1995. Testing significance of incongruence. Cladistic 10: 315-319.

Felsentein, J. 1985. Confidence limits on phylogenies: an approach using the bootstrap. Evolution 39: 783-791.

Franchet, A. 1885. Plantae Davidianae ex Sinarum imperio, Nouvelles Archives du Muséum d'Histoire Naturelle. Paris. Sér. 2. 8: 183-254.

Franchet, A. 1894. Les Adonis vivaces et leur repartition geogaphique. Bulletin de la Societe Philomatique de Paris. Sér. 8. 6: 80-93.

Fu, D. and O. R. Robinson. 2001. Adonis. In Flora of China. Vol. 6 (Caryophyllaceae through Lardizabalaceae). Wu, Z. Y., P. H. Raven and D. Y. Hong (eds.), Science Press, Beijing, and Missouri Botanical Garden Press, St. Louis. Pp. 389-391.

Fu, K. 2000. Adonis L. In Flora of Loess-plateaus Sinicae. Northwestern Institute of Botany. 1: 457-459. (in Chinese)
Hastings, W. K. 1970. Monte Carlo sampling methods using Markov chains and their applications. Biometrika 57: 97-109.

Hoot, S. B. 1995. Phylogeny of the Ranunculaceae based on preliminary $a t p \mathrm{~B}, r b c \mathrm{~L}$ and $18 \mathrm{~S}$ nuclear ribosomal DNA sequence data. Plant Systematics and Evolution, Suppl. 9: 241-251.

Huelsenbeck, J. P. and F. Ronquist. 2001. MrBayes: Bayesian inference of phylogenetic trees. Bioinformatics 17: 754-755.

Johansson, J. T. 1999. There large inversions in the chloroplast genomes and one loss of the chloroplast gene rps 16 suggest an early evolutionary split in the genus Adonis (Ranunculaceae). Plant Systematics and Evolution 218: 133-143.

Kaneko, S., N. Nakagoshi and Y. Isagi. 2008. Origin of the endangered tetraploid Adonis ramosa (Ranunculaceae) assessed with chloroplast and nuclear DNA sequence data. Acta Phytotaxonomica et Geobotanica 59: 165-174.

Kimura, M. 1980. A simple method for estimation evolutionary rates of base substitution through comparative studies of nucleotide sequences. Journal of Molecular Evolution 16: 111-120.

Lee, C. H., S. Lee, Y. B. Suh, S. H. Yeau and N. S. Lee. 2003. A morphological reexamination on the genus Adonis L. sensu lato (Ranunculaceae) in Korea. Korean Journal of Plant Taxonomy 33: 435-454. (in Korean)

Lee, Y. N. 2004. Adonis amurensis var. pseudoamurensis Y. N. Lee. Bulletin of Korea Plant Research Institute 4: 38.

Lee, Y. N. 2006. New Flora of Korea I. Kyohaksa, Seoul. (in Korean)

Linnaeus, C. 1753. Species Plantarum, vol. 1. Laurentius Salvius, Stockholm, $560 \mathrm{pp}$.

Mabberley, D. J. 1990. The Plant Book. Cambridge Univ. Press. New York.

Maximowicz, C. J. 1877. Diagnoses plantarum novarum asiaticarum. Bulletin de l'Académie Impériale des Sciences de Saint-Pétersbourg. St. Petersburg. 23: 305-391.

Meusel, H., E. Jaeger and E. Weinert. 1965. Vergleichende Chorologie der Zentraleuropaischen Flora. Stuttgart. G. Fischer.

Nishikawa, T. 1988. Botanical studies on Adonis amurensis Regel et Radde in Japan (Part 1). Journal of Hokkaido University of Education (Sect. IIB). 39(1): 1-35.

Nishikawa, T. 1989. Botanical studies on Adonis amurensis Regel et Radde in Japan (Part 2). Journal of Hokkaido University of Education (Sect. IIB). 39(2): 1-25.

Nishikawa, T. 1994. Phytogeographical study of Adonis (Ranunculaceae) in the Kushiro and Nemuro districts, Hokkaido. National Science Museum, Tokyo 27: 71-77. (in Japanese)

Nishikawa, T. and K. Ito. 2001. A new species of Adonis (Ranunculaceae) from Shikoku, western Japan. Bulletin of the 
National Science Museum, Tokyo Ser. B. 27: 79-83.

Nishikawa, T. and R. Takeshima. 1992. Geographical distribution of Adonis (Ranunculaceae) in the northern part of Hokkaido. National Science Museum, Tokyo 25: 87-96. (in Japanese)

Nishikawa, T. and Y. Kadota. 2006. Adonis. In Flora of Japan. Vol. IIa. Iwatsuki, K. et al. (eds.), Kodansha Ltd, Tokyo. Pp. 287288.

Park, C. W. 2007. Adonis. In The Genera of Vascular Plants of Korea. Flora of Korea Editorial Committee (ed.), Academy Publishing Co., Seoul. Pp. 184-185.

Posada, A. D. and K. A. Crandall. 1998. Modeltest: Testing the model of DNA substitution. Bioinformatics 14: 817-818.

Posada, A. D. and T. R. Buckley. 2004. Model selection and model averaging in phylogenetics: advantage of Akaike Information Criterion and Bayesian approaches over likelihood ratio tests. Systematic Biology 53: 793-808.

Poschkurlat, A. P. 1997. Systema sections Consiligo DC. generis Adonis L. Novosti Sistematiki Vysshikh Rastenii Moscow \& Leningrad [St. Petersburg] 14: 82-83.

Ren, Y., H. L. Chang, X. H. Tian, P. Song and P. K. Endress. 2009. Floral development in Adonideae (Ranunculaceae). Flora 204: 506-517.

Saitou, N. and M. Nei. 1987. The neighbor-joining method: a new for reconstructing phylogenetic trees. Molecular Biology and Evolution 4: 406-425.

Son, D. C. 2011. A taxonomic study on the genus Adonis L. (Ranunculaceae) in Korea. Hannam University, Daejeon. (in thesis for M. Sc.)

Son, D. C. 2015. A systematic study on the section Adonanthe of genus Adonis L. (Ranunculaceae) in East Asia. Hannam University, Daejeon. (in thesis for D. Sc.)

Son, D. C. and S. C. Ko. 2011. Taxonomy of the infraspecific taxa of Adonis amurensis Regel et Radde (Ranunculaceae). Korean Journal of Plant Taxonomy 41: 144-155. (in Korean)

Son, D. C. and S. C. Ko. 2012. A taxonomic review of Adonis pseudoamurensis W. T. Wang (Ranunculaceae). Korean Journal of Plant Taxonomy 42: 316-323. (in Korean)

Son, D. C. and S. C. Ko. 2013. Aggregated achenes and achene morphology of the Korean Adonis L. and its related taxa in East Asia. Korean Journal of Plant Taxonomy 43: 312-318. (in Korean)

Spach, E. 1839. Histoire Naturelle des Vegetaux. Phanerogames 7. Paris: Librairie Encyclopédique de Roret Pp. 186-192.

Suh, Y., J. Lee, S. Lee, C. H. Lee, S. H. Yeau and N. S. Lee. 2002. Molecular evidence for the taxonomic identity of Korean Adonis (Ranunculaceae). Journal of Plant Research 115: 217-223.

Sun, H., W. Mclewin and M. F. Fay. 2001. Molecular phylogeny of Helleborus (Ranunculaceae), with an emphasis on the East Asian-Mediterranean disjunction. Taxon 50: 1,001-1,018.

Swofford, D. L. 2003. PAUP*: Phylogenetic Analysis Using Parsimony (*and Other Methods), version 4.0b10. Sinauer Associates, Sunderland, Massachusetts.

Tamura, M. 1990. A new classification of the family Ranunculaceae 1. Acta Phytotaxonomica et Geobotanica 41: 93-101. (in Japanese)

Tamura, M. 1991. A new classification of the family Ranunculaceae 2. Acta Phytotaxonomica et Geobotanica 42: 177-187. (in Japanese)

Wang, L. A. and M. Y. Liu. 1988. Studies on the genus Adonis in northeast China. Bulletin of Botanical Research, Harbin 8 : 49-53 (in Chinese).

Wang, W. T. 1980. Adonis. In Flora of Reipublicae Popularis Sinicae. Tomus 28. Angiospermae: Dicotyledoneae: Ranunculaceae (2), Ranunculoideae. Wang, W. T. (ed.), Agendae Academiae Sinicae Edita, Beijing. Pp. 246-255. (in Chinese)

Wang, W. T. 1994a. Revision of Adonis (Ranunculaceae) I. Bulletin of Botanical Research, Harbin 14: 1-31. (in Chinese)

Wang, W. T. 1994b. Revision of Adonis (Ranunculaceae) II. Bulletin of Botanical Research, Harbin 14: 105-138. (in Chinese)

Wang, W. T. 1998. Adonis. In Higher Plants of China. Vol. 3. Fu, L. and T. Hong (eds.), Qingdao Publishing House, Qingdao. Pp. 546-549. (in Chinese)

White, T. J., T. Bruns, S. Lee and J. Taylor. 1990. Amplification and direct sequencing of fungal ribosomal RNA genes for phylogenetics. In PCR protocols: A Guide to Methods and Applications, Innis, M., K. Gelfand, J. Sninsky and T. White (eds.), Academic Press, San Diego, California, USA. Pp. 315322. 